\title{
Dexfenfluramine, Fluoxetine, and Weight Loss Among Female Carbohydrate Cravers
}

Judith Wurtman, Ph.D., Richard Wurtman, M.D., Eliot Berry, M.D., Ray Gleason, Ph.D., Hannah Goldberg, B.A., Janine McDermott, B.S., Merton Kahne, M.D., and Rita Tsay, M.S.

The consumption of excess calories as carbohydrates (CHO)-rich, protein-poor snacks characterizes the vvereating of obese $\mathrm{CHO}$ cravers, premenstrual women, patients with Seasonal Affective Disorder, and former smokers. This specific appetite for $\mathrm{CHOs}$ may involve brain serotonin, as the synthesis and release of this neurotransmitter can increase following consumption of CHO-rich foods. To examine whether weight loss produced by serotoninergic drugs involves a selective reduction in $\mathrm{CHO}$ intake, obese females who consumed at least $30 \%$ of their daily calories from $\mathrm{CHO}$-rich snacks were treated with dexfenfluramine ([DFI $15 \mathrm{mg}$ b.i.d.); fluoxetine ([FL] $20 \mathrm{mg}$ t.i.d.); or placebo (PL) for 12 weeks. Weekly weight loss for 25 of 29 PL completers was
$0.22 \mathrm{~kg} \pm 0.06$ (mean \pm SEM); for 21 of $28 \mathrm{DF}$ completers, $0.56 \pm 0.08 \mathrm{~kg}$; and for 18 of $30 \mathrm{FL}$ completers, $0.58 \pm 0.09 \mathrm{~kg}(P L<D F=F L ; p=.039)$. Seven FL subjects, 2 PL subjects, and 1 DF subject withdrew from the study due to side effects; other withdrawals were due to intercurrent illness or personal problems. Prior to treatment, subjects consumed over $40 \%$ of their daily $\mathrm{CHO}$ intake from snacks. Both of the drugs selectively decreased $\mathrm{CHO}$ snack intake $(p<0.05)$; $D F$, but not FL, also decreased meal CHO intake ( $p<$ .025). These results suggest that weight loss following treatment with serotoninergic drugs may relate to a selective decrease in $\mathrm{CHO}$ appetite.

[Neuropsychopharmacology 9:201-210, 1993]
KEY WORDS: Fluoxetine; Dexfenfluramine; Obesity; Appetite; Carbohydrate

Dexfenfluramine (DF) is utilized in many countries for the treatment of human obesity, particularly that associated with the consumption of excessive amounts of carbohydrate (CHO)-rich foods (Ditschuneit et al. 1991; Guy-Grand et al. 1989; Wurtman et al. 1985). Fluoxetine (FL), currently in use as an antidepressant drug, has recently been found to be an effective anorectic agent as well (Ferguson and Feighner 1987; Kutnowski et al. 1990; Levine et al. 1987; Wise 1992; Zerbe 1987). Both drugs act to enhance serotonin-mediated

From the Clinical Research Center, Massachusetts Institute of Technology, Cambridge, Massachusetts.

Address correspondence to: Judith J. Wurtman, Ph.D., Clinical Research Center E17-438, Massachusetts Institute of Technology, Cambridge, MA 02139.

Received November 24, 1992; revised March 15, 1993 and May 26, 1993; accepted May 31, 1993. brain neurotransmission by blocking brain serotonin reuptake; DF through its metabolite, nordexfenfluramine, also releases serotonin into synapses.

It has been suggested that the weight loss produced by these drugs may be related to their effect in specifically decreasing the excessive intake of $\mathrm{CHO}$-rich foods (Wurtman et al. 1985; Ferguson and Feighner 1987). Because such foods are usually rich in fat, reducing $\mathrm{CHO}$ intake can account for a substantial reduction in total calorie intake (Wurtman et al. 1985; Ferguson and Feighner 1987). Brain serotonin appears to influence $\mathrm{CHO}$ consumption; evidence from studies in which animals or human volunteers were treated with dietary or pharmacologic interventions that increase serotonin-mediated neurotransmission indicates selective decreases in consumption of $\mathrm{CHO}$-rich foods (Blundell 1992; Leibowitz and Shor-Posner 1987; Luo and Li 1991; Wurtman et al. 1983; Wurtman and Wurtman 1979). When animals are treated with anorectic doses of $\mathrm{DF}$ or $\mathrm{FL}$, the subsequent reduction in calorie intake 
is also associated with a selective decrease in $\mathrm{CHO}$ consumption; protein intake remains unchanged (Luo and Li 1991; Wurtman and Wurtman 1979). In contrast, anorectic drugs that affect catecholamine-mediated neurotransmission nonselectively decrease food intake (Moses and Wurtman 1984). Obese humans who typically consume excessive amounts of $\mathrm{CHO}$ foods, particularly as snacks, reduce their $\mathrm{CHO}$ snack intake by approximately $40 \%$ in response to $\mathrm{DF}$, but they do not significantly alter their protein consumption. Anorectic doses of FL might be expected to similarly affect $\mathrm{CHO}$ intake because of this drug's similarity to DF in enhancing serotonin-mediated neurotransmission. However, recent studies indicate that anorectic doses of FL may affect catecholaminergic as well as serotoninergic neurotransmission (Garattini et al. 1992; Grignaschi and Samanin in press) by inhibiting catecholamine reuptake; moreover, rats treated with metergoline, a serotonin-receptor antagonist, still respond to the anorectic actions of FL but not DF (Garattini et al. 1992; Samanin et al. 1989). If FL-mediatedanorexia in humans also involves catecholaminergic mechanisms, then the drug's influence on macronutrient intake may differ from that of DF. Little is known from clinical trials about specific changes in food intake following FL administration. One study did investigate changes in appetite; the results indicated a lessening of appetite for $\mathrm{CHO}$ rich foods among individuals treated with FL but not with placebo (Ferguson and Feighner 1987). However, that study was not designed to measure food intake directly and relied instead on subjective perception. The present study compares the effects of DF and FL treatments on calorie, macronutrient intake, and weight loss among obese women. The subject population was restricted to individuals who claimed to consume excessive amounts of CHO-rich foods as snacks (" $\mathrm{CHO}$ cravers"), and whose pretreatment pattern of food intake confirmed this claim.

\section{METHODS AND SUBJECTS}

\section{Subject Recruitment and Screening}

Subjects were recruited through newspaper, radio, and mass transit advertisements directed at women who were $40 \mathrm{lbs}$ to $60 \mathrm{lbs}$ above ideal body weight, according to the Metropolitan Life Insurance Height and Weight Table for midpoint frames (Metropolitan Height and Weight Tables 1983), and who perceived their obesity as being sustained by an excessive appetite for sweet and starchy snack foods. Potential subjects were asked to complete and return questionnaires on their health history, menstrual symptomatology, weight-loss history, annual patterns of weight gain and loss, and typical daily snack patterns. Acceptance into the outpatient screening procedure required the applicant to be in good general health, a nonsmoker, and at least 3 months beyond the completion of any weight loss program. Applicants who reported moderate-to-severe premenstrual mood and appetite changes and/or a clear pattern of seasonal weight gain and loss were not considered for the study because such fluctuations in mood and appetite could potentially influence the treatment responses during the study. Eligible subjects were then evaluated at the Massachusetts Institute of Technology (MIT) Clinical Research Center (CRC). The subjects were asked to sign a consent form that had been approved by the MIT Committee on Use of Humans as Experimental Subjects (COUHES) and the CRC Advisory Committee. They then underwent examination by a physician that included a history and physical examination, urinalysis, electrocardiogram, thyroid profile, HGC, complete blood count, and blood profile (BPRO: glucose, blood urea nitrogen, creatinine, total protein, albumin, calcium, phosphorous, total bilirubin, uric acid, cholesterol, triglyceride, sodium, potassium, chloride, total carbon dioxide, alkaline phosphate, lactic dehydrogenase, serum glutamic, oxaloacetic transaminase, serum glutamic-pyruvic transaminase).

\section{Baseline Food Intake}

One hundred and two subjects who were in good physical health (as determined by physical examination, blood chemistry, and electrocardiogram) and whose weight status met protocol criteria were asked to participate in a 4-day outpatient measurement of their meal and snack intakes to identify those whose food intake reflected a consistent appetite for $\mathrm{CHO}$-rich snack foods. Previous studies have shown that most obese subjects who claimed that their consumption of sweet and starchy snacks was associated with an inability to lose weight did in fact eat at least $30 \%$ of their total daily calories in the form of between-meal CHO-rich snacks (Wurtman et al. 1987).

A two-phase approach was used to identify subjects who would meet our criteria for $\mathrm{CHO}$ craving. Prior to admission to the screening component of the study, interested subjects filled out a mailed questionnaire detailing their typical pattern of snack intake. This questionnaire asked them if they snacked daily and, if so, to indicate when during the day they snacked. The subjects indicated, from a long list of protein-, $\mathrm{CHO}-$, and fat-rich snacks as well as fruits and vegetables, which snacks they were most likely to eat. The questionnaire defined "snacking" as eating between or after meals when subjects were not hungry. Subjects who indicated that they snacked daily on only $\mathrm{CHO}$. rich foods were then asked to participate in the baseline measurement procedure.

The dietary department of the CRC provided the subjects with an assortment of isocaloric, low-fat, 
Table 1. Meal and Snack Foods

\begin{tabular}{lccrrrr}
\hline & $\begin{array}{c}\text { Amount } \\
\text { (g) }\end{array}$ & KCal & $\begin{array}{c}\text { Protein } \\
\text { (g) }\end{array}$ & $\begin{array}{c}\text { CHO } \\
\text { (g) }\end{array}$ & $\begin{array}{c}\text { Fat } \\
\text { (g) }\end{array}$ & \% KCal/Fat \\
\hline Meal item & & & & & & \\
Oatbran fruit bar & 43 & 150 & 4 & 28 & 4 & 24 \\
Cinnamon raisin roll & 37 & 147 & 3 & 18 & 7 & 43 \\
Cottage cheese with chives & 143 & 150 & 17.5 & 3 & 6.25 & 38 \\
Pasta salad & 105 & 150 & 4 & 25 & 4 & 24 \\
Seafood salad & 105 & 142 & 22 & 0 & 5 & 32 \\
Soft roll & 57 & 150 & 4 & 36 & 2 & 12 \\
Tuna with diet dressing & 128 & 140 & 23 & 2 & 3 & 19 \\
Chicken with BBQ sauce & 106 & 150 & 26 & 2 & 4 & 24 \\
Stuffed potato with cheese & 135 & 154 & 5 & 28 & 3 & 18 \\
Cod with cheese & 111 & 150 & 23 & 0 & 6.75 & 40 \\
Snack item & & & & & & \\
Cereal (Frootloops) & 27 & 100 & 1 & 24 & 0 & 0 \\
Cereal (Quaker OH's) & 44 & 120 & 1 & 22 & 3 & 22 \\
Pretzel sticks & 28 & 110 & 3 & 21 & 2 & 16 \\
Luncheon meat & 71 & 100 & 13 & 3 & 5 & 45 \\
Cheese & 28 & 80 & 7 & 1 & 5 & 56 \\
Fig bars & 30 & 106 & 1 & 20 & 2 & 17 \\
Goldfish crackers (cheese) & 30 & 140 & 3 & 18 & 6 & 38 \\
\hline
\end{tabular}

protein-rich, and $\mathrm{CHO}$-rich foods in excess of what they might consume (Table 1). Meal foods contained an average of $32 \% \mathrm{Kcal}$ from fat, and snack foods contained $26 \%$ Kcal from fat. The foods were packaged in preweighed, easily transported containers for consumption away from home. The meal and snack food items provided by the study were relatively low in fat to make them compatible with the objectives of a weight-loss study. Subjects were told to eat spontaneously, not to restrict their food intake, and to consume only

and the foods designated as snack foods for in-between meal snacks. A simple log book was provided in which the subject could check off the foods actually consumed against a printed list and could note the time of day when each food was eaten. The log book was designed such that the subjects could record whether they ate a particular food item as a meal or snack food, as well as the time of food consumption. Because it was possible that they would also consume foods other than those provided by the study, they were asked to note their consumption of those foods as well. All food containers and all uneaten food were returned to the dietician for weighing. The subjects were weighed prior to the food intake measurement and on the day of completion.

\section{Activity Levels}

Subjects kept a record of their physical activity for 4 days coincident with the period of baseline food intake measurement. None of the subjects engaged in any formal exercise regime; physical activity was limited to that necessary for maintaining daily routines (i.e., walking from the car to work, climbing stairs in the home, meal preparation, carrying groceries, doing laundry, etc.) Most of the subjects' waking hours were spent seated.

\section{Study Format}

Subjects whose $\mathrm{CHO}$ intake as snacks met the protocol criteria were randomly assigned to a FL, DF, or placebo (PL) treatment group. The study was conducted in double-blind fashion; subjects received identical packets of three pills that provided a total of $60 \mathrm{mg} \mathrm{FL}$, $30 \mathrm{mg}$ DF, or PL. They were told to take one pill in the morning, one at noon, and one in the early evening; the noon pill in the DF packet was a placebo. The doses of FL and DF were those known to produce anorectic effects (Guy-Grand et al. 1989; Levine et al. 1987). Subjects were given a food plan that instructed them as to the number of servings and portion sizes they should consume to obtain their total daily nutrient requirements. The dietary information emphasized the importance of eating a variety of foods, and subjects were given exchange lists containing examples of nutrientdense, low-fat foods.

No additional information on weight loss was offered to the subjects. There was no discussion between the staff and subjects on exercise, behavioral modification, stressful events that might have affected weight loss, or nutritional information other than repeated admonitions to consume as little fat as possible. Because the subjects were entered individually into the study, no interaction between subjects was possible. The staff was uniformly considerate and kind to the subjects, many of whom reported after completion 
that weekly contact with the staff was an important positive component in their compliance with the study.

\section{Measurements}

Weight, vital signs, side effects, and assessments of mood and premenstrual symptomatology were obtained on the day prior to the initiation of drug treatment. The presence of depressive symptoms over the previous week was assessed using the intervieweradministered Hamilton Depression Rating Scale (HDRS) (Hamilton 1967), the self-administered Profile of Mood States (POMS) (McNair et al. 1971), and the Center for Epidemiological Studies-Depression (CESD) (Radloff 1977) test. Subjects also filled out the Standford Sleepiness Scale (SSS) (Hoddes et al. 1973) and the Menstrual Symptomatology Questionnaire (MSQ) (Abraham 1981). Baseline side effects were monitored by recording spontaneous descriptions of mood and physical status during the previous week. Following this, subjects were asked to report any illness or major life event that occurred during the previous week and to note the week of their menstrual cycle or, for menopausal women, the week of hormone replacement therapy. Blood was drawn for baseline drug levels and BPRO.

Subjects were treated for 12 weeks; they returned to the CRC weekly to receive their medications. At that time, their vital signs, side effects, and weight were evaluated and measured, and they filled out the POMS, CES-D, SSS, and MSQ forms. The research nurse reviewed the side-effect report with each subject prior to dispensing medication for the following week. The side-effect reports were also subsequently reviewed by the study physicians. Every fourth week, blood was drawn for measurement of drug levels and BPRO, and food intake was monitored over 4 days, using the methods described above for baseline food intake.

Two weeks following the end of the treatment period, subjects returned to the CRC for a posttreatment assessment of drug levels and BPRO. At that time, they met with the research staff and were given information on dietary intake and exercise. When subjects dropped out of the study, one of the research physicians sent a full report of their medical and treatment status, along with their reasons for withdrawal, to the MIT COUHES.

\section{Data Analysis}

Weight, food intake, and test scores were analyzed using a two-factor repeated-measures analysis of variance with time as the repeated measure. Food intake was averaged for each 4-day measurement period. Posthoc pairwise comparisons among study group and time means were tested for significance using the Newman-
Keuls test. Relationships between variables were tested for significance using Pearson's product moment correlation. Differences in distributions of dropouts and side effects among study groups were compared using the chi-square statistic. Data are expressed as means with standard errors of the mean used as the measure of dispersion. Statistical significance was determined at $p \leqslant .05$.

\section{RESULTS}

Eighty-seven women qualified for entry into the study on the basis of data from the baseline food intake screening. All of them met our criteria for $\mathrm{CHO}$ cravers, consuming more than $40 \%$ of their total $\mathrm{CHO}$ intake as high-CHO snack foods and more than $30 \%$ of their total daily calories as such foods. (Protein intake from snacks accounted for slightly more than $20 \%$ of their total daily protein intake.) Fifteen subjects were eliminated during the screening period because they restricted their calorie consumption during the food intake measurement period to under $1000 \mathrm{Kcal}$ a day and admitted to the diet staff that they wanted to use the baseline period to initiate their weight loss regimen. Fat was a fixed constituent of the meal and snack foods; subjects could not alter the fat contents of the foods by, for example, choosing to eat or avoid high-fat ingredients such as butter or mayonnaise. Although the foods varied somewhat in the number of grams of fat they contained, the amount of fat the subject consumed was determined mainly by the number of servings of protein or CHO-rich foods that she chose to eat. However, the fat content of the foods was kept as low as possible because the subjects would be eating the same foods during the weight loss component of the study, and we did not want the foods used in the study to be incompatible with weight loss.

The three groups of subjects were similar in age, body mass index (BMI) (Table 2) and in reporting a sedentary level of physical activity (Table 2); none showed evidence of depression on self-reported a interviewer-rated tests of mood at the time they entered the study (Table 2).

Subjects were entered singly into each treatment group; 64 subjects completed the study: the PL group consisted of 25 of 29 initial subjects, DF 21 of 28 subjects, and FL 18 of 30 subjects (Table 2). Weight loss per week was calculated for all subjects (i.e., for those who completed the study and for those who dropped out). No difference was found in the rate of weekly weight loss between completers and dropouts at the time the latter withdrew from the study; hence, the results given represent those of the total group. The weekly rates of weight loss were similar for the two drug treatment groups and significantly greater than that of the PL treatment group $(p=.039)$. The PL-treated sub- 
Table 2. Subject Profile

\begin{tabular}{lccc}
\hline & \multicolumn{3}{c}{ Treatment } \\
\cline { 2 - 4 } Variable & Placebo & Dexfenfluramine & Fluoxetine \\
\hline Number & 29 & 28 & 30 \\
Age & $39.5 \pm 1.7$ & $41.2 \pm 1.7$ & $41.0 \pm 1.9$ \\
Height $(\mathrm{cm})$ & $164.2 \pm 0.9$ & $163.7 \pm 1.1$ & $165.0 \pm 1.2$ \\
Weight $(\mathrm{kg})$ & $88.33 \pm 1.5$ & $85.7 \pm 1.7$ & $90.1 \pm 1.9$ \\
BMI & $32.8 \pm 0.5$ & $32.0 \pm 0.5$ & $33.1 \pm 0.6$ \\
Completers & 25 & 21 & 18 \\
Dropouts & 7 & 4 & 12 \\
Physical Activity & Inactive & Inactive & Inactive \\
HDRS & $8.5 \pm 1.4$ & $10.1 \pm 1.8$ & $7.4 \pm 1.4$ \\
CES-D & $9.92 \pm 1.23$ & $12.95 \pm 2.77$ & $8.89 \pm 2.34$ \\
\hline
\end{tabular}

jects lost $0.22 \pm 0.06 \mathrm{~kg}$ per week, DF subjects lost $0.56 \pm 0.08 \mathrm{~kg}$ per week, and FL subjects lost $0.58 \pm$ $0.09 \mathrm{~kg} /$ per week (groups include both completers and noncompleters). The cumulative weight loss (of completers) at the end of the treatment period was also similar between drug-treated subjects and significantly more than among those receiving PL $(p<.05)$ (Fig. 1). The PL-treated subjects lost $3.0 \pm .74 \mathrm{~kg}$, DF subjects lost $6.6 \pm 0.96 \mathrm{~kg}$, and FL subjects lost $7.1 \pm 1.09 \mathrm{~kg}$. The PL-treated subjects showed a small weight gain of approximately $0.14 \pm 0.19 \mathrm{~kg}$ at the end of the 5 th and th treatment weeks, and net losses at the end of all the other weeks. Because the amount of weight to be lost was similar but not identical among subjects, weight loss was also calculated as a percent of the amount of weight that needed to be lost for each subject to attain ideal body weight. The PL-treated subjects lost $11.3 \%$ of this weight, DF subjects lost $27 \%$, and FL subjects lost 26\% (Fig. 2).

\section{Food Intake}

All subjects consumed more than $40 \%$ of their total $\mathrm{CHO}$ intake from snacks during the baseline food in-

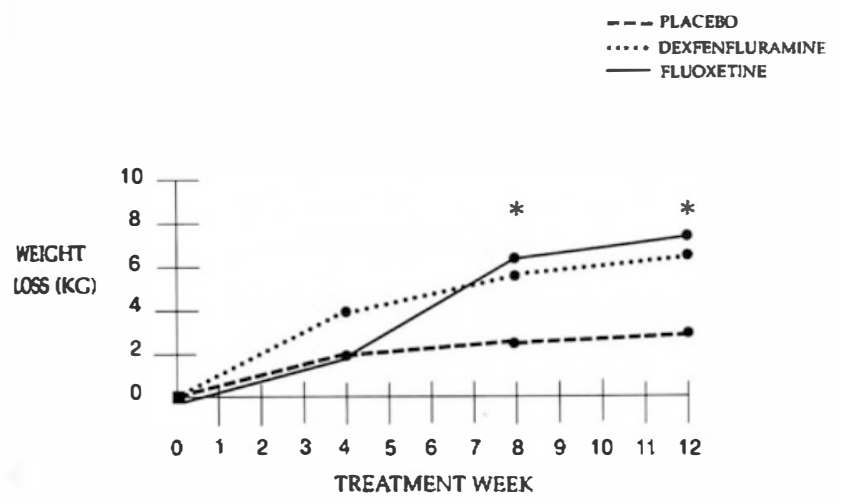

Figure 1. Cumulative weight loss $(\mathrm{kg})$ in subjects receiving placebo(PL), dexfenfluramine ([DF] $15 \mathrm{mg}$, twice daily), and duoxetine ([FL] $20 \mathrm{mg}$, three times daily) for 12 weeks. ${ }^{*} p<.05$ differs from PL-treated group. take period. Protein intake from snacks accounted for slightly more than $20 \%$ of total daily protein intake. Daily calorie consumption was similar between all groups prior to the initiation of treatment (Table 3). Subjects consumed approximately 1250 calories from meals and 790 calories from snacks during the baseline period of food intake measurement. Their calorie intake during the study may have underrepresented what they normally consumed inasmuch as the foods supplied by the $\mathrm{CRC}$ were probably lower in fat than those the subjects would choose to consume at home or in a restaurant (Table 3).

All treatments resulted in a decrease in calorie intake from meals and snacks; the reductions, however, were significantly greater for the drug-treated groups than for PL group. Decreased CHO intake from meals and snacks accounted for the greatest effect of the drugs on food intake (Table 3). By the end of the third treatment period, snack $\mathrm{CHO}$ intake by the PL-treated subjects was decreased by $48 \%$ of baseline. The DF-treated subjects had decreased snack $\mathrm{CHO}$ intake by $75 \%$, and FL-treated subjects decreased snack $\mathrm{CHO}$ intake by $60 \%$. The decreases with DF and FL treatment were significantly greater than with PL $(p<.05)$.

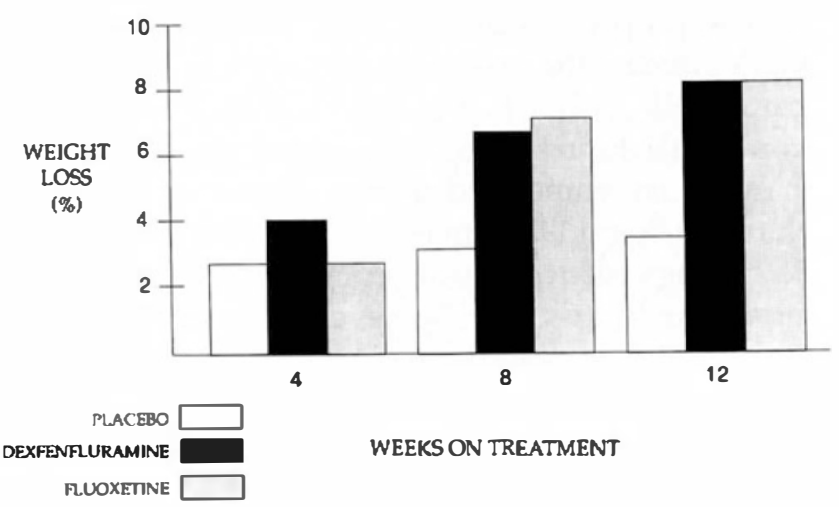

Figure 2. Weight loss as the percent of the amount to be lost to attain ideal body weight according to the Metropolitan Life Insurance Height/Weight Tables for Women. ${ }^{\star} p<.05$ differs from PL-treated group. 
Table 3. Food Intake During Baseline Period and Following 12 Weeks of Treatment

\begin{tabular}{lccc}
\hline & Placebo & Dexenfluramine & Fluoxetine \\
\hline $\begin{array}{c}\text { Calories } \\
\text { Meal }\end{array}$ & & & \\
$\quad$ Baseline & $1208 \pm 41$ & $1251 \pm 70$ & $1287 \pm 76$ \\
Week 12 & $1126 \pm 51$ & $946 \pm 40 \ddagger$ & $1079 \pm 85^{\star}$ \\
Snack & & & \\
Baseline & $720 \pm 49$ & $816 \pm 210$ & $837 \pm 71$ \\
Week 12 & $368 \pm 66$ & $212 \pm 38^{\star}$ & $312 \pm 49^{\dagger}$ \\
Protein (g) & & & \\
Meal & & & \\
Baseline & $86 \pm 3$ & $92 \pm 9$ & $93 \pm 6$ \\
Week 12 & $78 \pm 5$ & $68 \pm 3^{\dagger}$ & $77 \pm 5^{\star}$ \\
Snack & & & \\
Baseline & $21 \pm 3$ & $27 \pm 4$ & $27 \pm 4$ \\
Week 12 & $10 \pm 2$ & $7 \pm 2^{\star}$ & $8 \pm 1^{\dagger}$ \\
CHO (g) & & & \\
Meal & & $152 \pm 9$ & $154 \pm 10$ \\
Baseline & $151 \pm 7$ & $118 \pm 5^{\dagger}$ & $128 \pm 13 \mathrm{NS}$ \\
Week 12 & $141 \pm 9$ & & \\
Snack & & & \\
Baseline & $109 \pm 8$ & $113 \pm 16$ & $125 \pm 11$ \\
Week 12 & $57 \pm 11$ & $30 \pm 5^{\star}$ & $50 \pm 8^{\star}$
\end{tabular}

* Decrease is greater than placebo $p<.05$.

+ Decrease is greater than placebo $p<.025$.

$\ddagger$ Decrease is greater than placebo $p<.002$.

NS is not significant.

Subjects were allowed to choose their meal and snack foods from among a variety of isocaloric, isofat, protein- and carbohydrate-rich items. The foods were supplied in excess of what the subjects normally consumed. Fat content was kept as low as possible, and its intake varied in relation to the consumption of the meal and snack foods. Food intake was measured over 4 days prior to the start of the drug treatment and over the 4,8 , and 12 weeks subjects were still receiving treatment.

CHO intake from meals was affected only by DF treatment ( $p<.025$ vs. PL). Although those subjects receiving $\mathrm{FL}$ ate less $\mathrm{CHO}$ at mealtimes than $\mathrm{PL}$, the difference was not significant (Table 3).

Protein intake from snacks represented the protein present in the designated "protein snacks" and the small quantities of protein present in "CHO snacks" (Table 3). The proportion of total daily protein intake from snacks during the treatment periods was similar in all groups (PL, 11\%; DF, 9\%; and FL, 9\%). Protein intake from meals during the baseline period was much higher than the recommended dietary allowance (Food and Nutrition Board 1989) among all three treatment groups. Both drugs reduced meal protein intake significantly more than PL $(p<.05)$; however, none of the subjects in any group decreased protein intake below the recommended amount.

Weight loss significantly correlated with decreased snack CHO intake among the DF group $(r=0.485, p=$ .03 ) and with decreased mealtime protein intake among the FL group ( $r=0.566, p=.014)$. Weight loss in the PL group was not correlated with any specific changes in macronutrient intake.

\section{Side Effects and Dropouts}

The number of subjects who withdrew from the study due to side effects differed significantly $(p<.02)$ between the FL-treated subjects (seven) and the two other treatment groups (two, PL; one, DF) (Table 4). Lack of weight loss accounted for the withdrawal of two addjtional FL-treated subjects; all other subjects withdrew because of intercurrent illness or personal problems that interfered with their ability to comply with the study schedule. Almost all subjects, regardless of treatment, reported side effects during the study (PL, 24 of 29; DF, 23 of 28; FL, 27 of 30), and more side effects were reported during the first 4 weeks of the study than during the subsequent 2 months (Table 5).

The number of subjects reporting headaches was similar among all three treatment groups; anxiety was slightly more common among the PL-treated subjects (Table 5). The types of side effects reported by subjects on the two drug treatments differed. Dry mouth $(30 \%)$ and headache (18\%) accounted for the majority of side effects reported by those on DF, whereas insomnia $(22 \%)$ and fatigue (18\%) were the most common side effects reported by those on FL (Table 5). The FL-treated subjects reported significantly more sleep disturbances and fatigue during the entire treatment period than the other two treatment groups $(p<.005)$; the DF-treated subjects reported significantly more complaints of dry mouth $(p<.005)$.

Subjects who were menstruating were asked to complete a menstrual symptom checklist each week that rated changes in mood, appetite, sleep, and somatic symptoms. Among PL-treated subjects, self-reported appetite tended to increase premenstrually; both DFand FL-treated subjects showed significantly less of an increase during the first treatment month $(p<.018)$. Depression was monitored through the use of the interviewer-administered HDRS, the self-reported POMS, and the CES-D scale prior to treatment initiation. The latter two tests were filled out weekly by the subjects throughout the 12 treatment weeks. No significant alterations from baseline scores were observed among any of the subjects, regardless of treatment.

\section{DISCUSSION}

Obese female subjects who consumed at least $40 \%$ of their total daily $\mathrm{CHO}$ intake from snack foods - and at least $30 \%$ of their total calories from such foodsresponded to treatment with DF or Fl by losing, on average, twice as much weight per week as PL-treated subjects. Moreover, both drugs were similar in helping subjects to lose, in 12 weeks, slightly more than a quarter of the weight needed to attain ideal body weight for their height. 
Table 4. Subjects Withdrawing Because of Side Effects

\begin{tabular}{|c|c|c|c|}
\hline $\begin{array}{l}\text { Subject } \\
\text { No. }\end{array}$ & $\begin{array}{l}\text { Treatment } \\
\text { Week } \\
\text { Completed }\end{array}$ & Treatment & Side Effects \\
\hline 8400 & 1 & Fluoxetine & $\begin{array}{l}\text { "Numb-headed," "heavy-headed," } \\
\text { nausea, fatigue }\end{array}$ \\
\hline 8444 & 1 & Fluoxetine & $\begin{array}{l}\text { Tachycardia, dry mouth, nausea, } \\
\text { headache, insomnia, accelerated } \\
\text { transit time, light-headed, dizzy, } \\
\text { restless }\end{array}$ \\
\hline 8459 & 2 & Fluoxetine & $\begin{array}{l}\text { "Too many side effects," fatigue, } \\
\text { "numb-headed," "heavy-headed" }\end{array}$ \\
\hline 8474 & 1 & Fluoxetine & Headache, itching \\
\hline 8557 & 2 & Fluoxetine & $\begin{array}{l}\text { Headache, insomnia, fatigue \& tremor, } \\
\text { dizzy, "spacey," nausea, upper GI } \\
\text { distress, dry mouth }\end{array}$ \\
\hline 8682 & 7 & Fluoxetine & $\begin{array}{l}\text { Drowsiness, muscle aches, fatigue, } \\
\text { insomnia, headache, diarrhea }\end{array}$ \\
\hline 8734 & 7 & Fluoxetine & $\begin{array}{l}\text { Insomnia, dry mouth, "feels different } \\
\text { physicially," memory \& concentration } \\
\text { disturbances, yawning, anxiety, } \\
\text { chills, "goosebumps," vomiting, } \\
\text { diarrhea, vivid dreams during which } \\
\text { she hit her husband }\end{array}$ \\
\hline 8492 & 6 & Placebo & $\begin{array}{l}\text { Abnormal values for plasma } \\
\text { electrolytes }\end{array}$ \\
\hline 8558 & 10 & Placebo & $\begin{array}{l}\text { Visual disturbance, fatigue, headache, } \\
\text { palpitations, eructations, dizzy, } \\
\text { anxiety, taste disturbance, drowsiness }\end{array}$ \\
\hline 8454 & 4 & Dexfenfluramine & $\begin{array}{l}\text { Elevated blood pressure, fatigue, } \\
\text { tremor, insomnia, taste disturbance }\end{array}$ \\
\hline
\end{tabular}

The monthly food intake measurements indicated that both drugs similarly affected $\mathrm{CHO}$ intake from snacks, reducing it significantly more than PL treatment. Only DF-treated subjects, however, demonstrated a significant correlation between weight loss and decreased $\mathrm{CHO}$ snack intake; weight loss among FLtreated correlated with decreased protein intake from meals.

Both drugs have well-established effects on weight loss: $\mathrm{DF}(30 \mathrm{mg})$ has been shown to cause more weight loss than PL in a large number of studies (Cairella et al. 1991; Ditschuneit et al. 1991; Finer et al. 1985, 1987; Guy-Grand et al. 1989; Noble 1990). Many short-term trials have shown the drug to reduce weight in obese patients over 3- to 6-month periods even among patients who were refractory to medical and nutritional supervision (Noble 1990). In a 1-year placebo-controlled multicenter trial of 822 patients, weight loss during the first 6 months was greater in the DF-treated group than in the PL group ( $9.82 \mathrm{~kg}$ vs. $815 \mathrm{~kg}$ ); this loss was maintained during the second 6 months by DF patients, but not by PL-treated subjects, whose weight increased (Guy-Grand et al. 1989). In a group of obese subjects undergoing smoking withdrawal, drug treatment was associated with weight loss; in comparison, PL-treated subjects gained weight (Spring et al. 1991). Dexfenflura- mine also inhibited weight gain among subjects with a history of Seasonal Affective Disorder (O'Rourke et al. 1989).

Fluoxetine administered to obese subjects in daily doses ranging from $40 \mathrm{mg}$ to $80 \mathrm{mg}$ (Ferguson and Feighner 1987; Levine et al. 1987; Wise 1992) was significantly more effective than $P L$ in producing weight loss over 8-week periods. It has been reported (Pijl et al. 1991) that obese females treated for 6 weeks with $60 \mathrm{mg} /$ day of FL lost weight, whereas PL-treated subjects gained weight. Scientists (Orzack et al. 1990) have observed that treatment for 2 months with $20 \mathrm{mg} /$ day to $80 \mathrm{mg} /$ day of FL also caused weight loss among depressed obese patients, although treatment for 4 months caused weight gain among patients whose starting weight was normal for their height. We did not see any evidence of weight gain with FL treatment, although two subjects dropped out of the study due to lack of weight loss after 3 to 4 weeks of treatment. In a study lasting 52 weeks (Darga et al. 1991), it was found that FL (60 mg/day) treatment caused a maximum weight loss at week 29 , followed by substantial weight gain, such that no differences were seen in total weight loss between drug and placebo treatment by the end of the study. Weight gain over a 4 - to 24 -month period ranged from 10 to 30 pounds. 
Table 5. Number of Reports of Most Common Side Effects During Each 4-Week Period of Study

\begin{tabular}{|c|c|c|c|}
\hline & Weeks 1-4 & Weeks 5-8 & Weeks 9-12 \\
\hline \multicolumn{4}{|l|}{ Headache } \\
\hline Placebo & 15 & 7 & 10 \\
\hline Dexfenfluramine & 21 & 8 & 2 \\
\hline Fluoxetine & 17 & 11 & 5 \\
\hline \multicolumn{4}{|l|}{ Fatigue } \\
\hline Placebo & 6 & 6 & 4 \\
\hline Dexfenfluramine & 14 & 3 & 4 \\
\hline Fluoxetine & 16 & 11 & 4 \\
\hline \multicolumn{4}{|l|}{ Insomnia } \\
\hline Placebo & 2 & 4 & 0 \\
\hline Dexfenfluramine & 6 & 5 & 6 \\
\hline Fluoxetine & 16 & 13 & 9 \\
\hline \multicolumn{4}{|l|}{ Drowsiness } \\
\hline Placebo & 1 & 0 & 0 \\
\hline Dexfenfluramine & 4 & 2 & 0 \\
\hline Fluoxetine & 9 & 1 & 2 \\
\hline \multicolumn{4}{|l|}{ Anxiety } \\
\hline Placebo & 3 & 2 & 1 \\
\hline Dexfenfluramine & 3 & 0 & 0 \\
\hline Fluoxetine & 4 & 0 & 0 \\
\hline \multicolumn{4}{|l|}{ Dry mouth } \\
\hline Placebo & 8 & 9 & 6 \\
\hline Dexfenfluramine & 25 & 14 & 13 \\
\hline Fluoxetine & 12 & 7 & 4 \\
\hline \multicolumn{4}{|l|}{ Diarrhea } \\
\hline Placebo & 0 & 1 & 0 \\
\hline Dexfenfluramine & 10 & 2 & 0 \\
\hline Fluoxetine & 1 & 1 & 0 \\
\hline \multicolumn{4}{|l|}{ Nausea } \\
\hline Placebo & 1 & 3 & 1 \\
\hline Dexfenfluramine & 1 & 0 & 0 \\
\hline Fluoxetine & 7 & 3 & 1 \\
\hline \multicolumn{4}{|l|}{ Upper GI Distress } \\
\hline Placebo & 4 & 1 & 0 \\
\hline Dexfenfluramine & 4 & 1 & 2 \\
\hline Fluoxetine & 3 & 1 & 2 \\
\hline \multicolumn{4}{|l|}{ Constipation } \\
\hline Placebo & 1 & 0 & 0 \\
\hline Dexfenfluramine & 3 & 3 & 2 \\
\hline Fluoxetine & 5 & 0 & 0 \\
\hline \multicolumn{4}{|l|}{ Polyuria } \\
\hline Placebo & 0 & 0 & 0 \\
\hline Dexfenfluramine & 3 & 0 & 0 \\
\hline Fluoxetine & 1 & 1 & 0 \\
\hline \multicolumn{4}{|l|}{$\begin{array}{l}\text { Menstrual } \\
\text { disturbances }\end{array}$} \\
\hline Placebo & 0 & 1 & 0 \\
\hline Dexfenfluramine & 3 & 3 & 7 \\
\hline Fluoxetine & 4 & 1 & 1 \\
\hline
\end{tabular}

These data include symptoms reported by all subjects, both completers and dropouts. Side effects were assessed weekly by spontaneous report and recorded by a trained investigator.

Direct measurements of food intake revealed a significantly greater decrease in consumption of $\mathrm{CHO}$ rich foods among drug-treated than among PL-treated subjects. These findings confirm earlier animal and clinical studies in which treatment with drugs that increase intrasynaptic serotonin was shown to suppress $\mathrm{CHO}$ intake. That serotonin participates in the regulation of CHO intake(Blundell 1992; Leibowitz and Shor-Posner 1987 ) is based on the observation that increased serotonin synthesis following consumption of $\mathrm{CHO}$-rich meals (Blum et al. 1992; Fernstrom and Wurtman 1973; Lyons and Truswell 1988) leads to a subsequent decrease in CHO intake (Wurtman et al. 1983). A similar decrease in $\mathrm{CHO}$, but not protein, intake is seen after intrasynaptic serotonin levels are increased by treatment with anorectic drugs (Cangiano et al. 1992; Hill and Blundell 1986; Luo and $\mathrm{Li} \mathrm{1991;} \mathrm{Wurtman} \mathrm{and}$ Wurtman 1979). Administration of FL or DF to animals given access to isoenergetic diets differing in protein and $\mathrm{CHO}$ contents decreased the consumption of only the high CHO diet (Cangiano et al. 1992; Hill and Blundell 1986; Luo and Li 1991; Wurtman and Wurtman 1979). Similarly, DF administration to CHO cravers (Wurtman et al. 1985; Wurtman et al. 1987), women with Late Luteal Dysphoric Syndrome (Brzezinski et al. 1990), and individuals going through smoking withdrawal selectively suppressed $\mathrm{CHO}$ but not protein intake. Although measured subjectively, the decreased appetite for $\mathrm{CHO}$-rich foods previously reported by subjects treated with FL provides additional evidence of the participation of serotonin in controlling $\mathrm{CHO}$ intake (Ferguson and Feighner 1987). The results of the present study provide additional evidence that both $D F$ and FL exert their anorectic effect primarily through serotonin-mediated decreases in $\mathrm{CHO}$ intake and confirm through direct measurement of food intake the observation of Ferguson and Feighner of a subjective decrease in appetite for CHO-rich foods (Ferguson and Feighner 1987).

There is some disagreement, however, as to whether treatments that enhance serotonin availability affect the intake of protein and fat as well as of $\mathrm{CHO}$. It has been found (Cangiano et al. 1992) that obese individuals treated with 5-hydroxytryptophan signifcantly reduced both fat and $\mathrm{CHO}$ consumption. A decline in protein intake was also reported in this study, but this was not significant. In the present study, as in those conducted earlier in our laboratory, DF treatment did decrease protein intake but the magnitude of this change was considerably smaller than the reduction in CHO consumption (Wurtman et al. 1985). The effect of altering serotonin availability through dng treatment on macronutrient intake may be affected by the weight of the subjects and the duration of treatment. In 1992, scientists treated nonobese males with DF and measured food intake several hours after the drug was administered. They found that DF had no effecton protein, fat, or sweet $\mathrm{CHO}$ intake and reduced $\mathrm{CHO}$ consumption only from nonsweet $\mathrm{CHO}$ foods such as bread (Goodall et al. 1992).

Finally, the effects of agents such as DF on macronutrient intake in animals may be dependent on the 
particular stage of the diurnal cycle during which feeding is measured. Weiss et al. (1990) found that rats treated with DF selectively reduced their consumption of $\mathrm{CHO}$ only at the onset of the nocturnal period (i.e., when the animals eat most of their food). No effect on macronutrient intake was observed in the middle and late hours of the dark phase (Weiss et al. 1990). The availability of new selective serotonin reuptake inhibitors such as sertraline and paroxetine may help resolve the issues involving macronutrient specificity.

Protein intake from meals was decreased more by drug than by PL treatment; none of the treatments, however, decreased protein intake below the recommended dietary allowance (Food and Nutrition Board 1989). The effects of DF and FL on the consumption of high-fat foods such as butter, cream, salad dressings, cheese, and bacon were not assessed in this study. However, because most of the protein- and $\mathrm{CHO}$-rich test foods used in the study also contained fat, the reduction of food intake during the treatment period inevitably led to a decrease in fat intake and in the intake of fat calories.

Measurement of the correlation between weight loss and macronutrient intake, revealed differences between the two drugs; decreased $\mathrm{CHO}$ intake from snacks was correlated with weight loss among the DFtreated subjects, whereas protein intake from meals was correlated with weight loss among FL-treated subjects. It is difficult to interpret these results because FL decreased CHO snack intake to the same degree as DF. More information would be needed concerning food intake in the subjects' usual surroundings to verify these correlations.

The two drugs differed in their side-effect profiles. The most common side effects seen among DF-treated subjects were dry mouth, fatigue, and diarrhea. The FL-treated subjects reported insomnia and fatigue as the most persistent side effects. Most subjects in all three groups reported side effects, especially during the first month of treatment; those receiving FL, however, were the most likely to drop out of the study in response to their symptoms. We examined the weight loss, mood profile, initial weight, and health history of the seven FL-group dropout subjects and found no pretreatment differences between them and the subjects who remained in the study. Only one DF subject left the study for health reasons (increased blood pressure); two on PL also left due to side effects. Recent work on the mechanisms of action of the two drugs (Garattini et al. 1992; Garattini 1987; Grignaschi and Samanin in press; Samanin

used in the treatment of obesity ( $60 \mathrm{mg} /$ day), FL may enhance dopaminergic as well as serotoninergic transmission(Garattini et al. 1992; Garattini 1987; Grignaschi and Samanin in press; Samanin et al. 1989). This could account for the drug's side-effect profile and the re- bound-eating after its discontinuation as reported in other studies.

The foods that we used for measurement of calorie and macronutrient intake were relatively low in fat, with most of the CHO-rich snacks containing $2 \mathrm{~g}$ or $3 \mathrm{~g}$ of fat and the protein snacks containing $5 \mathrm{~g}$ or less of fat (Table 1). This may account for the somewhat lowcalorie intake of the subjects at baseline; presumably their calorie and fat consumption would be higher from foods they selected for themselves. We found, however, that our subjects responded positively to the availability of very low $\mathrm{CHO}$ foods, especially snack foods, and informed us that they were unaware until entering the study that it was possible to snack without consuming large amounts of fat. It may thus be that the PL-treated subjects responded as well as they did because they learned from our study that they could satisfy their $\mathrm{CHO}$ cravings without consuming foods that were also high in fat.

\section{ACKNOWLEDGMENTS}

These studies were supported in part by a grant to the MIT Clinical Research Center from the National Institutes of Health (RR00088) and The Center for Brain Science and Metabolism Charitable Trust.

\section{REFERENCES}

Abraham EG (1981): Premenstrual tension. Curr Probl Obstet Gynecol 3:1-39

Blum I, Vered Y, Graff E, Grosskopf Y, Don R, Harsat A, Raz $O$ (1992): The influence of meal composition on plasma serotonin and norepinephrine concentrations. Metabolism 41:137-140

Blundell J (1992): Serotonin and the biology of feeding. Am J Clin Nutr 55:155S-159S

Brzezinski A, Wurtman J, Wurtman R, Gleason R, Greenfield $J$, Nader T (1990): d-Fenfluramine suppresses the increased calorie and carbohydrate intakes and improves the mood of women with premenstrual depression. Obstet Gynecol 76:296-301

Cairella G, Cairella M, Graziani P, Mirante MG (1991): Changes in food consumption of obese patients induced by dietary treatment combined with dexfenfluramine. Int J Obes 15 (Suppl 1):3

Cangiano C, Ceci F, Cascino A, DelBen M, Laviano A, Muscaritoli M, Antonucci F, Ross-Fanelli F (1992): Eating behavior and adherence to dietary prescriptions in obese adult subjects treated with 5-hydroxytryptophan. Am J Clin Nutr 56:863-867

Darga L, Carroll-Michals L, Botsford S, Lucas C (1991): Fluoxetine's effect on weight loss in obese subjects. Am J Clin Nutr 54:321-325

Ditschuneit HH, Fulda U, Flechtner-Mors M, Ditschuneit H (1991): Dexfenfluramine in the long-term treatment of refractory obesity. Int J Obes 15 (Suppl 1):69 (Abstract) 
Ferguson JM, Feighner JP (1987): Fluoxetine-induced weight loss in overweight non-depressed humans. Int J Obes 11 (Suppl 3):163-170

Fernstrom JD, Wurtman RJ (1973): Control of brain 5HT content by dietary carbohydrates. In Barchas J, Usdin E (eds), Serotonin and Behavior. New York, Academic Press, pp 121-128

Finer N, Craddock D, Levielle R, Keen H (1985): Dextrofenfluramine in the treatment of refractory obesity. Curr Ther Res 38:847-854

Finer N, Craddock D, Levielle R, Keen H (1987): Prolonged weight loss with dexfenfluramine treatment in obese patients. Diabet Metab 13:598-602

Food and Nutrition Board (1989): Recommended Dietary Allowances, 10th ed. Washington, DC, National Academy of Sciences

Garattini S (1987): Mechanisms of the anorectic activity of dextrofenfluramine. In Bender AE, Brookes LJ (eds), Body Weight Control: The Physiology, Clinical Treatment and Prevention of Obesity. Edinburgh, Church Livingstone, pp 261-270

Garattini S, Bizzi A, Codegoni AM, Caccia S, Mennini T (1992): Progress report on the anorexia induced by drugs believed to mimic some of the effects of serotonin on the central nervous system. Am J Clin Nutr 55:160S-166S

Goodall E, Feeney S, McGuirk J, Silverstone T (1992): A comparison of the effects of $\mathrm{d}$ - and I-fenfluramine and $\mathrm{d}$-amphetamine on energy and macronutrient intake in human subjects. Psychopharmacology 106:221-227

Grignaschi G, Samanin R (1993): Role of brain serotonin and catecholamines in the feeding suppressant effect of fluoxetine. Neuropharmacology (In press)

Guy-Grand B, Crepaldi G, Lefebvre P, Apelbaum M, Gries $A$, Turner $P$ (1989): International trial of long-term dexfenfluramine in obesity. Lancet 2:1142-1144

Hamilton M (1967): Development of a rating scale for primary depressive illness. Br J Clin Psychol 6:278-296

Hill AJ, Blundell JE (1986): Model system for investigating the actions of anorectic drugs: Effects of $d$-fenfluramine on food intake, nutrient selection, food preferences, meal patterns, hunger, and satiety in healthy human subjects. In Ferari E, Brambilla F (eds), Disorders of Eating Behavior: A Psychoneuroendocrine Approach. Oxford, Pergamon Press, pp 377-380

Hoddes E, Zarcone V, SmytheH, Phillips R, Dement W (1973): Quantification of sleepiness: A new approach. Psychophysiology 10:431-436

Kutnowski M, Daubresse JC, Friedman H(1990): Eight weeks of fluoxetine therapy in obese patients with impaired glucose tolerance. Int J Obes 14 (Suppl 2):48 (Abstract)

Leibowitz SF, Shor-Posner G (1987): Brain serotonin and eating behavior. Appetite 7:1-4

Levine LR, Rosenblatt S, Bosomworth J (1987): Use of a serotonin reuptake inhibitor, fluoxetine, in the treatment of obesity. Int J Obes 11 (Suppl 3):185-190

Luo SQ, Li ET (1991): Effects of repeated administration of serotoninergic agonists on diet selection and body weight in rats. Pharmacol Biochem Behav 38:395-500
Lyons P, Truswell S (1988): A serotonin precursor influenced by type of carbohydrate meal in healthy adults. Am JClin Nutr 47:433-439

McNair D, Lorr M, Droppelman L (1971): Profile of Mood States [Manual]. San Diego, CA, Educational Testing Service, pp 5-29

Metropolitan Height and Weight Tables (1983): Stat Bull Metrop Life Insur Co 64:2

Moses P, Wurtman R (1984): The ability of certain anorexic drugs to suppress food consumption depends on the nutrient composition of the test diet. Life Sci 35:1297-1300

Noble R (1990): A six-month study of the effects of dexfenfluramine on partially successful dieters. Curr Ther Res 47: 612-619

O'Rourke D, Wurtman J, Wurtman R, Chebli R, Gleason R (1989): Treatment of seasonal depression with d-fenfluramine. J Clin Psychol 50:343-347

Orzack M, Friedman L, Marby D (1990): Weight changes on fluoxetine as a function of baseline weight in depressed outpatients. Psychopharmacol Bull 26:327-330

Pijl H, Koppeschaar HP, Willekens FL, Op de Kampl, Veldhuis HD, Meinders AE (1991): Effect of serotonin reuptake inhibition by fluoxetine on body weight and spontaneous food choice in obesity. Int J Obes 15 (Suppl 3):237-242

Radloff L (1977): The CES-D scale: A self-report depression scale for research in the general population. Appl Psychol Measurement 1:385-401

Samanin R, Mennini T, Bendotti C, Barone D, Caccia S, Garattini S (1989): Evidence that central 5-HT-2 receptors do not play an important role in the anorectic activity of d-fenfluramine in the rat. Neuropharmacology 28:465469

Spring B, Wurtman J, Gleason R, Kessler K, Wurtman R (1991): Weight gain and withdrawal symptoms after smoking cessation: A preventive intervention using d-fenfluramine. Health Psychol 10:216-223

Weiss G, Rogacki N, Fueg A, Buchen D, Leibowitz S (1990): Impact of hypothalamic d-norfenfluramine and peripheral d-fenfluramine injection on macronutrient intake in the rat. Brain Res Bull 25:849-859

Wise SD (1992): Clinical studies with fluoxetine in obesity. Am J Clin Nutr 55:181S-184S

Wurtman JJ, Wurtman RJ (1979): Drugs that enhance central serotoninergic transmission diminish elective carbohydrate consumption by rats. Life Sci $24: 795-804$

Wurtman J, Wurtman R, Mark S, Tsay R, Gilbert W, Growdon J (1985): Dextrofenfluramine selectively suppresses carbohydrate snacking by obese subjects. Int J Eat Dis 4:89-99

Wurtman JJ, Moses P, Wurtman RJ (1983): Prior carbohydrate consumption affects the amount of carbohydrate rats choose to eat. J Nutr 113:70-78

Wurtman JJ, Wurtman RJ, Reynolds S, Tsay R, Chew B(1987): $\mathrm{d}$-Fenfluramine suppresses snack intake among carbohydrate cravers but not among noncarbohydrate cravers. Intnatl J Eat Dis 6:687-699

Zerbe RL (1987): Safety of fluoxetine in the treatment of obesity. Int J Obes 11 (Suppl 3):191-199 